\title{
Analysis of the Prosperous Family Card Program Policy during the Covid-19 Pandemic
}

\author{
Mohammad Yunus ${ }^{1}$, Muh. Alias ${ }^{1}$ \\ *Corresponding: myunusayat7@gmail.com \\ ${ }^{1}$ Department of State Administration, Faculty of Social and Political Sciences, University of East \\ Indonesia, Indonesia
}

Received: November 12, 2020

Received in Revised: November 29, 2020

Accepted: December 7, 2020

\begin{abstract}
The purpose of this research is to investigate the policy of the Prosperous Family Card Program in Tellang Kere Village of Tellu Limpoe District, Bone Regency. The research method used is a qualitatively descriptive. This method will provide a complete picture of social phenomena. Data collection techniques applied were observation and interview with key informants; Secretary of the sub-district head, Head of Public Service Section, Head and Village Secretary, Village Head, Community leader, prosperous family card's recipient community, additional informant: ewarong village agent. The results of the research indicated that the policy of the Prosperous Family Card Program in Tellang Kere Village of Tellu Limpoe District, Bone regency had not been effective. Some obstacles occurred in the location, namely firstly, the lack of education and complete socialization to recipients of The Prosperous Family Card, inactive social assistance so that many people still do not understand the benefits and objectives of the policy. Secondly, the limitations of the internet network forced the village agents to collect beneficiary families somewhere to make withdrawal transactions through Electronic Data Capture, this took timeconsuming. Thirdly, the data of the recipient of the Prosperous Family Card was often missed and not meticulous but not accumulated in the following month, and the last, monotonous menu had the potential to raise cholesterol that had an impact the risk of heart attack and diabetes, nevertheless, the public felt that this program had the benefits especially in the time of COVID19 pandemic.
\end{abstract}

Keywords: Prosperous Family Card, Program, Policy

\section{Introduction}

The focus of public policy is not only what the government does, but also what the government does not do. It is whatever the government does not do that has a significant impact on society as is the case with actions taken by the government including in terms of community welfare (Papadakis, 1992; Hicks \& Esping-Andersen, 2005; Lindbom, 2007).

The government has issued several policies to reduce poverty for 25.14 million people $(9.41 \%)$ of Indonesia's population who are at the poverty line, (Central Statistics Agency, 2019). These policies include; Law Number 5 of 2000 concerning the National Development Program which contains; poverty reduction strategies through the creation of opportunities, community empowerment by increasing access to economic and political resources. Then Presidential Regulation Number 166 of 2014 concerning the Program for Accelerating Poverty Reduction in 
article 2: (1) To accelerate poverty reduction, the government establishes social protection programs in the form of: Prosperous Family Savings Program, Smart Indonesia Program and Healthy Indonesia Program. It was continued again in the Presidential Instruction of the Republic of Indonesia Number 7 of 2014 concerning the Implementation of the Prosperous Family Savings Program, the Smart Indonesia Program, and the Healthy Indonesia Program to Build Productive Families.

In this policy, there are 3 cards, one of which is the Prosperous Family Card Program (KKS) card which marks the underprivileged. Through the implementation of this program, the use of technology was introduced to reach underprivileged people so that program distribution could be better and more efficient. The Prosperous Family Savings Program for Prosperous Family Card holders is a program of providing non-cash assistance in the form of savings provided to 15.5 million underprivileged families throughout Indonesia. Each family gets Rp.200,000 per month, this card will be filled in every 2 months, consisting of one 1 million families provided in the form of digital financial services by providing sim cards, and the remaining 14.5 million families are given in the form of postal gyro gradually on in 2015.

Bone Regency has an area of 4,559 km2 with a built area of 2,747.36 hectares, covering $27 \mathrm{sub}$ districts, 328 villages and 44 sub-districts. Based on data from the National Team for the Acceleration of Poverty Reduction (TNP2K), the number of poor people in Bone Regency in 2017 was 314,569 people from 80,157 heads of families, one of the villages included is Tellang Kere Village, Tellu Limpoe District, Bone Regency. Based on the author's previous observations in Tellang Kere Village, Tellu Limpoe District, Bone Regency, as one of the villages implementing the Prosperous Family Card Program, it was found that the distribution and appointment of Prosperous Family Card recipients caused social jealousy. The following is an excerpt from the author's interview with the Village Secretary of Tellang Kere Hermanto "The determination of the recipients of the Prosperous Family Card is not from us, the village officials, but has been determined by the Bone Regency Government, as a result many are not on target, causing social upheaval and jealousy, as well as the socialization of not bringing all card recipients. , the impact is that there are some who do not understand how to use it, and some have even ripped the card, because they wondered why they got money.

Previous research by Kurniawan (2016) has been carried out on the Prosperous Family Card Program in Samarinda City, Anggleni (2018) in Palembang City, Rahmah et al (2019) in Nagari Canduang Koto Laweh and Syahriawti et al (2016). The results of the study stated that it was not yet effective, the mechanism and socialization were not optimal, and there was no precise understanding. This means that the research only looks at the mechanism, so that the results are not optimal, it can be seen from the word that seems one-sided.

There are differences in implementation with this research, this study focuses more on the analysis of the process; starting from educational activities and program socialization, namely how many times it was implemented and the number of receiving participants who attended, how the selection and determination of recipients, was it based on data and facts from the underprivileged population from the local government, training in using cards, was it carried out in direct practice, as a reinforcement for the implementation of the achievements well seen in the presentation of key informants and additional informants and also carried out in remote villages located at 1500 meters above sea level (asl). The more urgency of this research is that while the information on the implementation of the KKS Program is still causing a lot of chaos in several regions, President Joko Widodo has instead launched the "Sakti Card" (KIP-College, Cheap 
Groceries Cards, Pre-Employment Cards). implementing a similar card policy, especially in remote areas with internet networks.

The Prosperous Family Card Program is one of the programs created by the government in an effort to accelerate poverty reduction. The Prosperous Family Card program form is non-cash food assistance transferred through a savings account for underprivileged families that has received validation from the Directorate General of Poor Management of the Ministry of Social Affairs.

This Prosperous Family Card (KKS) is used as a transaction tool through opening an account at a channeling bank in collaboration with e-warong in the village to distribute non-cash government assistance connected to the internet network. This non-cash assistance is equivalent to Rp.200,000 / month / family or $10 \mathrm{~kg}$ of rice, $2 \mathrm{~kg}$ of sugar, vegetable oil, wheat flour and eggs.

The Purpose of the Prosperous Family Card Program; (1) to assist the poor in meeting their basic needs, (2) to prevent the decline in the welfare level of the poor and vulnerable due to economic difficulties, (3) to reduce poverty problems and improve the welfare of the poor, (4) to build productive families by improving community welfare programs, (5) can increase the dignity of underprivileged families.

Benefits of the Prosperous Family Card Program includes (1) improving education for future generations. a. school age children must go to school, (2) improve health quality; a. health checks for pregnant women and toddlers, b. health examination of household members, c. adopting a healthy lifestyle for the elderly, (3) changing financial management behavior through opening a savings account.

Based on the Regulation of the Minister of Social Affairs Number 11 of 2018 concerning Distribution of Non-Cash Food Assistance (BPNT) in Article 9 the mechanism for distributing BPNT through stages; (a) registration and/or opening of accounts, (b) education and socialization, (c) distribution, (d) purchasing of goods, and its implementation refers to Presidential Instruction Number 7 of 2014. The purpose of this study is to analyze the Prosperous Family Card Program Policy in an effort acceleration of poverty reduction in Tellu Limpoe District Bone Regency, especially during the Covid-19 pandemic. The study at Tellang Kere Village, Tellu Limpoe District, Bone Regency focused on the theory of policy implementation according to Edward III, 1980 on communication, resources, disposition and bureaucratic structures.

\section{Methods}

The research method is descriptive with a qualitative approach to provide a complete and indepth description of social phenomena about the implementation of these policies at the location. Data collection techniques used observation and interviews with 11 key informants, namely; Secretary of the sub-district, Head of Public Service Section, Village Head and Secretary, Hamlet Head, community leaders, community KKS recipients, and 1 additional informant, namely: e-warong village agent. The data analysis technique uses the Spradley model qualitative data analysis technique, namely; descriptive observation, domin analysis, focused observation, taxonomic analysis, selected observations, component analysis and theme analysis (Moleong, 2010). Can be simplified; domein analysis, taxonomic analysis, component analysis and theme analysis, in order to obtain credible research results. 


\section{Results and Discussion}

To analyze the policy of the Prosperous Family Card Program in this study, the theory of policy implementation according to Edward III (1980) and Widodo (2010) stated that communication, resources, dispositions and bureaucratic structures refer to the Minister of Social Affairs Regulation Number 11 of 2018 concerning the Distribution of Food Aid Non-Cash (BPNT) in Article 9 that the BPNT distribution mechanism goes through stages; registration and or opening of accounts, education and outreach, distribution, purchase of goods, and implementation refer to Presidential Instruction Number 7 of 2014.

\section{Communication}

Based on the technical guidelines for the distribution of Non-Cash Social Assistance in 2019, it is stated that the account opening mechanism is carried out collectively (account opening) according to the data that has been submitted by the Ministry of Social Affairs to the channeling bank with the Handover Official Report (BAST). This means that before data is valid for recipients of each family, the government must first collect data. What happened in Tellang Kere Village, the transmission dimension of communication did not work, because the aim and target of data collection was only the government and BPS who knew, but the target group (poor families) had not been previously validated. So that the data collection technique and the decision to determine the Beneficiary Family (KPM) were complained by the residents, it was considered unfair. As said by an informant that out of 309 families, only 191 families received in stages complete with KKS card along with a PIN (Personal Identification Number), but among the number who have not received it, there are still classified as poor. To clarify the residents' complaints, the researcher asked the Head of the Tellu Limpoe District Public Service Section, according to the informant, that the data was taken based on the 2016 Economic Census by the Central Bureau of Statistics which was forwarded to the Directorate General for Handling the Poor, Ministry of Social Affairs. In this way, the consistency dimension of communication is ineffective, the evidence is that there is confusion over the measurement of the determination of the poor who receive the Prosperous Family Card Program.

This is in line with the results of research from Kurniawan (2016) which states that BPS seems unilateral, the data collection process for KKS recipients without involving the local government. Responding to the complaint, the Tellu Limpoe District Government acknowledged that there were differences in the perspective of the poor community's assessment, in which the community judged vehicle ownership, while the government assessed the level of income and family responsibilities, because the program was aimed at the head of the family. To erase this disappointment, the village apparatus continued to accommodate it by submitting it to other forms of assistance.

\section{Resources}

Based on the technical guidelines for implementation, education and outreach are carried out by the Ministry of Social Affairs and the Distribution Bank to the local government, then the regional government together with the channeling bank will continue to the KPM in the regions with the social assistant. The form of education and outreach is in the form of face-to-face meetings, assisted by printed media (posters) that contain explanations of policies and technicalities for using cards. Based on information from KKS recipients in Tellu Limpoe Subdistrict, it was true that there was one education and outreach at the Tellu Limpoe District Office in 2017, by one person, but at that time the number of participants who attended was not 
all KKS recipients, because it coincided with the rice planting season, also the explanation is less detailed (maximum) because of limited time, not practicing using the card. As a result, there are still many KKS recipients who do not understand, while the presence of assistants is also not optimal. This is what causes many Beneficiary Groups (KPM) to not know the technicalities of using the card, one of which is Kamaruddin (an informant) who ripped the card to find out how to get money from the card.

It is clear that there is a lack of education and outreach, especially for people with limited levels of education and understanding. This means that the officer as implementing policy resources is insufficient, only one person does it, it is impossible to explain the objectives, benefits of the policy and answer all questions from the community, as well as inconsistent and irresponsible social assistance resources. Resource information channels are also ineffective because they are only delivered once through face-to-face, there is no repetition of information in the form of meetings and evaluating program implementation, it is proven that many people do not understand. This is also found in research from Angleni (2018) which acknowledges the lack of outreach to all the poor and also research from Lasulika, (2020) shows a lack of socialization in public policy.

\section{Disposition}

Based on the Minister of Social Affairs Regulation Number 11 of 2018 Article 21, the distribution of assistance from the accounts of the Directorate General of Management of the Poor to the channeling bank then goes to the e-wallet account of the beneficiary family (KPM) Non-Cash Food Assistance (BPNT) no later than 30 calendar days. Based on information from the Tellang Kere Kasman village agent that it is true that every month they receive funds from the channeling bank (Bank Mandiri) every month a nominal amount for each KPM, but the dates are irregular, sometimes even one to five KKS holders do not receive (overlooked), however not accumulated in the following month, as experienced by; Neni, Kartia, Risna, Raddise, Tina in August 2020, next; Muslan, Herlina, Helang in September 2020. Another obstacle that occurred in Tellu Limpoe Subdistrict, especially Tellang Kere Village was the lack of internet networks, so that to make withdrawal transactions from the channeling bank the village agent (Kasman) had to collect KPM to a location provided by the network. and carrying EDC (electronic data capture). This was complained by the residents that it takes up one day of work. Thus the implementation of policies is ineffective, the attitude of policy implementers (disposition) is inadequate and lacks seriousness, resulting in negligence in data input, plus there is no serious effort to overcome the limitations of the internet network.

\section{Bureaucratic Structure}

In accordance with the Regulation of the Minister of Social Affairs Number 11 of 2018 concerning Distribution of Non-Cash Food Assistance (BPNT) article 9 Standard Operating Procedures (SOP) for the implementation of purchasing goods by exchanging KKS funds of Rp. 200,000 to village agents providing e-warong in the form of food every month. Since 2020, the types of goods have been determined in the form of: 4 racks of 120 eggs, 1 liter of vegetable oil and 1 liter of sugar. According to Suhartina (an informant) until now the exchange has never been a problem, the village agent always provides the foodstuffs before the exchange time. But the problem is the excessive nutrition of chicken eggs, as said by Tahera (an informant), every time you eat with her grandchildren, there are always eggs. The nutritional content of purebred chicken eggs consists of 150 calories, 12.5 grams of protein, 10 grams of fat and 1 gram of 
carbohydrates. The advantage of consuming 2 eggs per day has the potential to raise cholesterol and can trigger the risk of heart attack and diabetes, so KPM recipients hope there is a policy of alternating food menus. Based on this case, it can be seen that the bureaucratic structure implementing policies does not implement policies according to SOPs, does not solve problems comprehensively, but can actually create problems for the community.

The results of this study indicate that policy implementation is ineffective, the attitude of policy implementers (disposition) is inadequate and less serious, resulting in negligence of data input, plus there is no serious effort to overcome the limitations of the internet network. Disposition is one of the factors that have important consequences for effective policy implementation (Van Meter \& Van Horn., 1975; May \& Winter, 2009; Amir, 2020). If the implementers have a positive tendency or attitude or support for policy implementation, there is a high probability that policy implementation will be carried out in accordance with the initial decision. Then the bureaucratic structure that implements policies does not implement policies according to SOPs, does not solve problems in a comprehensive manner, but can actually create problems for the community. This is in accordance with the views of experts Ran (2013) \& Sander (2018) who state that the implementation of complex policies requires cooperation of many parties. When the bureaucratic structure is not conducive to the implementation of a policy, this will cause ineffectiveness and impede the implementation of the policy.

\section{Conclusion}

Education and outreach to KKS recipients were not comprehensive, card use practices were not carried out, social leaders were not active, so there were still many KKS recipients who did not understand, even damaged cards without knowing the benefits and objectives of the policy. The implementing resources were not thorough in collecting data on KKS recipients, it was proven that there were often things that were missed, but not accumulated in the following month. Having limited internet networks, so that they cannot access information, village agents are forced to collect KPM in one place to make fund withdrawal transactions via EDC, which is draining and time consuming. The food menu is monotonous, giving rise to a new problem of excess protein which has the potential to raise cholesterol which has an impact on the risk of heart attack and diabetes. The community feels the benefits of the KKS Program, especially during the Covid-19 pandemic.

\section{References}

Amir, A. (2020). Public Policy Implementation: Study on Educational Budgeting of Palopo. Journal La Sociale, 1(1), 5-11.

Anggleni, A. (2018). Implementasi Kebijakan Program Kartu Keluarga Sejahtera (KKS) dalam Meningkatkan Kesejahteraan Masyarakat Miskin di Kelurahan Sekip Jaya Kecamatan Kemuning Kota Palembang. Journal PPS UNISTI, 1(1), 24-39.

Central Statistics Agency. (2019). Persentasi Penduduk Miskin 2019. Available at: https://www.bps.go.id/pressrelease/2019/07/15/1629/persentase-penduduk-miskinmaret-2019-sebesar-9-41-persen.html

Hicks, A., \& Esping-Andersen, G. (2005). Comparative and historical studies of public policy and the welfare state. The handbook of political sociology: states, civil societies, and globalization, 509-525. 
Kurniawan. (2016). Studi Tentang Mekanisme Penyaluran Dana Perogram KKS (Kartu Keluarga Sejahtera) di Kelurahan Gunung Lingai Kecamatan Sungai Pinang Kota Samarinda. ejournal Ilmu Pemerintahan, 4(1), 156-166.

Lasulika, K., Akbar, M. F., \& Alkatiri, R. (2020). Policy Evaluation of Livable Houses Programs in Gorontalo City. International Journal of Social Welfare and Public Policy, 1(1), 2131.

Lindbom, A. (2007). Obfuscating retrenchment: Swedish welfare policy in the 1990s. Journal of Public Policy, 129-150.

May, P. J., \& Winter, S. C. (2009). Politicians, managers, and street-level bureaucrats: Influences on policy implementation. Journal of Public Administration Research and Theory, 19(3), 453-476.

Moleong, L.J. (2010). Metode Penelitian Kualitatif. Bandung: Remaja Rosdakarya.

Papadakis, E. (1992). Public opinion, public policy and the welfare state. Political Studies, 40(1), 21-37. 